\title{
Payment for ecosystem services, sustained behavioural change, and adaptive management: peasant perspectives in the Colombian Andes
}

\author{
TANYA M. HAYES* \\ Environmental Studies and Institute for Public Service, Seattle University, 901 12 th Avenue, PO Box 222000, Seattle, WA 98122, USA \\ and Center for the Study of Population, Institutions and Environmental Change (CIPEC), Indiana University, Bloomington, Indiana, USA \\ Date submitted: 12 April 2011; Date accepted: 17 January 2012; First published online: 14 March 2012
}

\section{SUMMARY}

Payment for ecosystem services (PES) has been widely promoted as an effective and efficient model for conservation; however, few studies have empirically examined how the market-based approach interacts with farmer's decision-making processes and their abilities to sustain new conservation practices. This paper examines the sustainability of a PES silvopastoral programme in Colombia from peasant farmers' perspectives. Programme participants were asked questions regarding their perceived ability to continue with the silvopastoral practices, the influence of the economic benefits and contracts on behavioural change, and the programme's impacts on self-determination, innovation and social learning; factors considered critical for sustained resource management. While the participants expressed a need for the PES programme practices, less than half stated that they would continue with the silvopastoral measures and only $13 \%$ understood that part of their contractual commitment was to conserve forests. Ten per cent of the participants considered themselves the principal decision-maker in the farm-level changes and only one participant had altered the prescribed practices, despite a common perception that some techniques were not suitable for the region. The results suggest a need to re-examine the degree to which the PES model in fact encourages adaptive management practices and sustained land-use behaviours in peasant communities.

Keymords: agricultural development, direct incentives, forest conservation, intrinsic motivation, Latin America, selfefficacy

\section{INTRODUCTION}

Conservation in the tropics appears to be on a new governance trajectory as market-based approaches look for ways to economically value ecosystem services, thereby making conservation more cost-effective. This neo-liberal approach

\footnotetext{
${ }^{*}$ Correspondence: Dr Tanya Hayes, Environmental Studies and Institute for Public Service, Seattle University, 901 12th Avenue, PO Box 222000, Seattle, WA 98122, USA e-mail: hayest@seattleu.edu
}

to conservation is presumed to be more effective than earlier top-down conservation practices and more recent 'populist' or bottom-up paradigms that emerged in the 1980s (Ferraro \& Kiss 2002; Robbins \& Williams 2005; Wunder 2006; Igoe \& Brockington 2007; Shiferaw et al. 2009). The benefits of the commodification of nature are heavily contested, as we lack a strong empirical foundation to understand how such market-based approaches may affect local resource rights, decision-making powers, sustainable resource management and livelihoods in poor, resource dependent communities (Liverman 2004; Igoe \& Brockington 2007; Sullivan 2009; Vatn 2010; van Dam 2011).

This paper examines the application of a payment for ecosystem services (PES) programme to promote sustainable pasture management (silvopastoral practices) and forest conservation in a watershed in the Eastern Andes, Colombia. Under the PES system, a buyer enters into a voluntary contract with a service provider (often a farmer or rural community) to purchase with cash or in-kind, an environmental service (Wunder 2005, 2006; Engel et al. 2008). Similar to recommendations derived from studies in agriculture and rural development, PES advocates contend that conservation practices must be economically rewarding and that this requires linking conservation to market systems (Dorward et al. 2004; Pagiola et al. 2005; Engel et al. 2008; Spielman et al. 2008; Shiferaw et al. 2009).

In Latin America, where agricultural expansion is a principal cause of deforestation (Angelsen \& Kaimowitz 1999; Geist \& Lambin 2001), international organizations such as the World Bank and the Food and Agricultural Organization of the United Nations (FAO) have promoted PES arrangements to encourage farmers to change to silvopastoral pasture management practices and conserve their remaining forest lands (Pagiola et al. 2007, 2008; Engel et al. 2008). Under the silvopastoral system, the use of live fences and dispersed trees in pastures, pasture fertilization and fodder banks are promoted to control agricultural expansion by improving the quality of smaller pasture parcels and thereby increasing the quantity of milk produced per cow per hectare (Nair 1985; Dagang \& Nair 2003; León \& Harvey 2006; Pagiola et al. 2007). In order to compensate farmers for these land-use changes, buyers (most often a non-governmental organization [NGO] or multilateral funding agency) cover the start-up costs of the silvopastoral system. It is assumed that if these initial costs are covered, the profits from increased milk production (estimated rates of return for Latin America are c. 4-14\%) will provide 
sufficient incentive for farmers to continue to conserve forests and sustainably manage pasture (Pagiola et al. 2005, 2007, 2008). In addition, the contingent contracts signed by the participants are presumed to further ensure compliance with the new land-use practices.

However, it remains uncertain whether the economic incentives and contingent contracts necessarily produce sustained land-use changes and conservation practices. Previous findings in agricultural adoption, conservation and development, economics and psychology point to several concerns in the PES model (Wilshusen et al. 2002; Igoe \& Brockington 2007; Pagiola et al. 2007; Engel et al. 2008; Murgueitio 2009; Sullivan 2009). First, it is questionable whether farmers' decision-making processes necessarily correspond to the PES model. While access to markets and increased production are clearly important for creating a programme that is economically rewarding, previous research indicates that smallholder farmers may not base their decisions solely on economic benefits in accordance with the neoclassical decision model (van den Bergh et al. 2000; Petheram \& Campbell 2010; Vignola et al. 2010; Gsottbauer \& van den Bergh 2011). Smallholder farmers are often faced with a number of household demands and temporal restrictions that they must satisfy via a complex set of livelihood strategies (Ashby 1985; Holden et al. 1998; Murgueitio 2009; Shiferaw et al. 2009). In weighing their land-use decisions, on-farm investments to sustain silvopastoral systems may not be perceived to offer the most immediate or practical benefits (Kiptot et al. 2007; Murgueitio 2009).

Second, there is little understanding of how the payments and practices are perceived by the farmers, and how they influence a farmer's decision to participate in a PES programme and sustain the silvopastoral practices. Research in social psychology, behavioural change and farmer decisionmaking illustrate that, in addition to economic considerations, cognitive factors, in particular an individual's perception of the problem and their perceived control over the proposed solution, often determine whether new farm management behaviours will be sustained (Bandura 1977; Bunch 1982; Ajzen 1991; Maddux \& DuCharme 1997; Hellin \& Haigh 2002; Hellin \& Schrader 2003; McGinty et al. 2008; Vignola et al. 2010). In models of behavioural change, perceived self-efficacy or the perceived control that an individual has to perform a particular activity is considered critical in predicting whether an individual will execute a specific behaviour (Bandura 1977; Ajzen 1991; Maddux \& DuCharme 1997; Grothman \& Patt 2005). Likewise, in agricultural development, perceived ownership over the practices and belief in personal ability and resources to make the requisite changes, irrespective of outside support, has also been found to be particularly important for sustained agricultural adoption, and many caution against the use of external incentives or donations (Bunch 1999; Hellin \& Haigh 2002; Robbins \& Williams 2005; McGinty et al. 2008). Kiptot et al. (2007) warn that external incentives may encourage the participation of pseudo-adopters, or those resource users that begin to use a new land-management technology to receive programme benefits, but stop the new practice once the benefits end. Even more troubling, research in economics has found that in some cases, payments have actually diminished the degree to which an individual was previously inclined to perform the desired activity (Cárdenas et al. 2000; Gneezy \& Rustichini 2000; Frey and Jegen 2001; Clements et al. 2010; Murtinho et al. 2010). Although PES scholars argue that the cash or in-kind payments are not donations, rather direct compensation for a service provided, given that many PES arrangements involve a wide array of buyers purchasing ill-defined environmental services, it may be difficult for a recipient to understand that they are engaging in a market transaction and not simply receiving a donation (Muradian et al. 2010).

Third, the effectiveness of the contingent contracts is dubious when applied in developing country settings amongst minimally literate populations. In many cases, semi-literate peoples may be asked to sign contracts written in complex legal terminology that commits them to land-use definitions and restrictions that are often foreign to their own constructs of human and environment interactions, committing them to extended periods that are difficult for them to envision (Escobar 1998; Holden et al. 1998; Ferraro 2008).

Finally, it is important to assess whether PES payments and contracts are able to instil characteristics such as selfdetermination, social learning and innovation, each found critical in sustained behavioural change and adaptive resource management (Pretty \& Shah 1997; Bunch 1999; Hagmann \& Chuma 2002; Hellin \& Haigh 2002; Johnson et al. 2003; Sumberg et al. 2003; Mercer 2004; Armitage 2005; Folke et al. 2005; Robbins \& Williams 2005; German et al. 2006; Spielman et al. 2008; Shiferaw et al. 2009). In studies of resource management, externally mandated land-use rules have been shown to reduce farmers' sense of ownership, thwart innovation and potentially 'crowd out' successful local resource management practices (Ostrom et al. 1990; Cárdenas et al. 2000; Agrawal \& Chhatre 2007). In the PES system, the reliance on binding contracts and land-use practices designed by external experts calls into question the degree to which farmers are able to assert their own autonomy over the landuse practices, experiment, and ultimately adapt the practices to current and future conditions on their farms.

Before continuing to promote the use of payments and contracts as a means of sustainable land management, a better understanding of how such market-based conservation systems are perceived by the recipients and actually operate 'on-the-ground' is required. I aim to draw on findings from the PES experiment underway in the Eastern Andes, Colombia in order to improve understanding of how the silvopastoral PES model of in-kind payments and contingent contracts influences farmers' commitment to and perceived ability to sustain the silvopastoral techniques and forest conservation measures. Specifically, I assess the sustainability of the PES silvopastoral system by examining (1) how farmers perceive the silvopastoral practices and their ability to continue with the practices, (2) the role of the economic benefits and contracts 
in encouraging behavioural change and (3) how the PES programme influences social learning, self-determination and innovation; these factors are considered critical for adaptive resource management and agricultural adoption.

\section{Oak Corridor, Eastern Andes, Colombia}

The Colombian Andes, given its biological richness and high levels of endemic species, is one of the most biodiverse regions in the world and a conservation hotspot (Armenteras et al. 2003). A conservation priority is the 'Oak Corridor' located in the departments of Santander and Boyacá, north of Bogota, on the western slope of the Eastern Andes. The Oak Corridor covers approximately $10730 \mathrm{~km}^{2}$ and contains the last remnants of the Colombian oak (Quercus humboildtii), and endemic and endangered flora and fauna.

In the Oak Corridor, the majority of the forest remnants are located on smallholder farmers' lands in the poorest regions of the two departments (Solano et al. 2005; Solano 2007). Most residents are mestizo (of mixed Spanish and indigenous descent) farmers, whose families first moved to the region in the early 1900s to exploit the forests for timber for the railroads, mines, construction materials for the nearby towns and cities, and the production of charcoal (Avella \& Cárdenas 2010). The region has a long history of minifundistas (farmers owning 1-5 ha of land) and microfundistas (farmers owning $<1$ ha of land), and, unlike other regions of Colombia, this sector has maintained a relatively stable tenure system and it has not faced displacement or other conflicts resulting from the civil war (Solano 2005).

Today, farmers maintain individual titles to their small parcels of land where they practise subsistence agriculture. Although technically illegal, small-scale timber extraction continues, mostly for local subsistence purposes (Solano 2005). In recent years, agricultural expansion, particularly extensive cattle grazing practices, has become the principal threat to the ecosystems in this region (Solano 2005; Avella \& Cárdenas 2010).

\section{PES silvopastoral programme}

In 2006, in an effort to curb agricultural expansion and promote sustainable livelihood development in the region, a consortium of national NGOs, in association with international donors and governmental agencies, created a silvopastoral PES programme. The programme was designed by Fundación Natura, a Colombian NGO with a history of promoting conservation in the region, and the Centre for the Investigation of Sustainable Agricultural Production Systems (CIPAV), an organization with over twenty years experience of working with agriculture and pasture management in Latin America. Although the NGOs did not conduct a formal market analysis, through discussions with local farmers, they identified poor milk production as one of the principal economic barriers, in addition to the costs required to transport the milk to the nearest city market (farmers often depend upon intermediaries for transportation). Thus, the project goals were to promote forest conservation by providing economic incentives for farmers to switch to more sustainable silvopastoral pasture management practices that would increase milk production and maintain the remaining forests on their private lands.

In order to be eligible to participate in the Oak Corridor programme, a farmer must be located in the designated watershed region, have forest (forest sizes range from 0.25 ha to $200 \mathrm{ha}$ ), have at least 3 ha of pasturelands that can be improved, and hold a de facto title to their land. Farmers sign a contract in which they pledge to adopt silvopastoral practices and protect their forests and, in exchange, they receive materials and extension support for three years to cover the initial start-up costs and pay them for agreeing to switch to a silvopastoral system and conserve their forest lands. The specific land-use practices that farmers commit to, in addition to forest conservation, include: (1) the use of fertilizers for pasturelands; (2) rotation through small parcels of pasturelands using electric wires to guide grazing; (3) live fences; and (4) fodder banks. In return, farmers receive as 'payment' several applications of fertilizers to recuperate pasturelands, fence posts, barbed wire and tree seedlings. If a farmer does not comply with the contract, he must pay back all of the investment made in his farm (c. US\$ $1444 \mathrm{ha}^{-1}$, September 2009).

\section{Study sites}

The specific study sites were seven communities, consisting on average of approximately 50 families, and located at $c$. 2500-3000 m elevation above sea level in the River Guacha watershed, along the border between two municipalities: Belen, Boyacá and Encino, Santander (Fig. 1). Although the communities neighbour a national park, park officials rarely visit the communities, as other regions are purported to be of greater political priority (local NGO worker, personal communication July 2011). Fundación Natura has a private forest reserve in the region and, in previous years, the organization has worked with women in neighbouring communities to produce knitted goods for sale in local markets. Prior to the introduction of the silvopastoral programme, however, the communities had not received any systematic external support for agriculture or pasture management and there were no formal agricultural or dairy cooperatives operating in the communities.

Residents practise small-scale potato and dairy farming on the surrounding hillsides. Farmers use minimal technology; land preparation is done by hand or using animals, and crops are rain-fed. While most farmers use chemical fertilizers and pesticides for potato production, few farmers fertilize their pasturelands, use green manures or fodder banks, and most cattle production is dependent upon relatively extensive grassland grazing. Residents sell their agricultural products (mostly potatoes) and dairy products to local and regional markets in cities that are located 1-2 $\mathrm{h}$ away by car. In recent years, many farmers have switched their crop lands to extensive pasture lands for dairy production, as the price of 


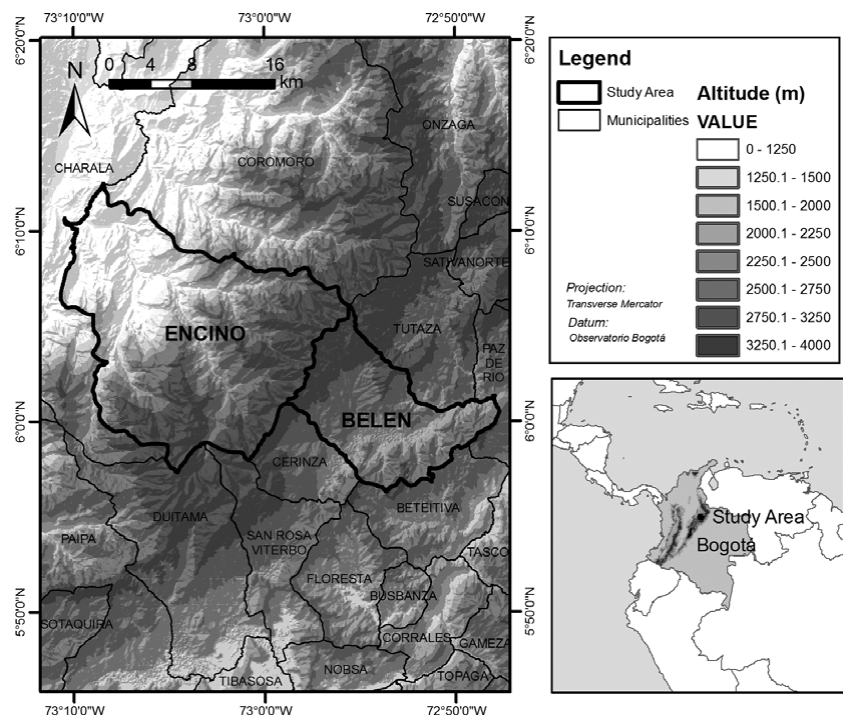

Figure 1 Study area in the Oak Forest Corridor, Colombia.

potatoes is considered to be more volatile than dairy (Solano et al. 2005; CIPAV, personal communication July 2008).

\section{METHODS}

This is an ex-ante assessment of a programme in progress. The programme began initially as a pilot project with 23 participants (2006-2009) who signed three-year contracts. In September 2009, the programme was expanded to include c. 60 new participants who signed five-year contracts. I conducted the research for this analysis July-September 2009. Data gathering included interviews with programme specialists, examination of NGO reports and presentations, farm visits and semi-structured interviews with select participants. In addition, I administered a participant questionnaire to both pilot project participants and new participants (Appendices $1 \& 2$, see supplementary material at Journals.cambridge.org/ENC). Twenty-one of the 23 pilot participants were interviewed in August 2009, just after the termination of the pilot project. In September 2009, an additional questionnaire was administered to 54 of the $c$. 60 new participants who had signed contracts at the end of August. The initial research design included interviews with non-participants; unfortunately, given the popularity of the programme, it was difficult to identify sufficient non-participants in the communities and they were thus not included in this analysis. For some questions, the new participants' responses may serve as baseline data to compare to the pilot participants, as the new participants had yet begun the silvopastoral practices or received programme benefits.

I structured the data gathering using previous work on agricultural adoption and adaptive management (Bunch 1982; Folke et al. 2005; Birner et al. 2006) and concepts from the Ajzen's theory of planned behaviour, which considers perceived behavioural control and stated intent to be strong predictors of actual behavioural achievement (Ajzen 1991, 2006). I aimed to assess how participants perceived farmlevel problems and the potential solutions that the PES programme offered, the likelihood that the silvopastoral and conservation practices would be sustained by participants, and the contribution that the PES programme made to the adaptive management capacities of the participants. I also gathered background information on the participants' age, education, household size, occupation, farm practices and community involvement.

In order to assess the participant's adoption of silvopastoral practices and the sustainability of said practices, the study measured: (1) participants' practices prior to beginning the programme; (2) pilot participants' stated intent to continue with programme practices; (3) pilot participants perceived behavioural control, or self-efficacy, assessed by participant's responses to whether they could continue to implement the practices without external assistance; (4) the economic viability of the programme when perceived benefits are compared with farmers competing economic priorities; and (5) participants' perceptions of the legitimacy of the contracts and their contractual commitments. Finally, I assessed the contributions of the Oak Corridor programme to adaptive management by analysing pilot participant's perceptions of self-determination (specifically who made the silvopastoral farm-level decisions), pilot participants experimentation with any of the pasture management practices, and by identifying social learning that had occurred with the pilot and new participants.

\section{RESULTS}

\section{Participants and their practices prior to programme participation}

The participants were generally middle-aged males (72\%), with a few years of primary education, maintaining an average of six cows on five hectares of pasturelands (Table 1). The characteristics of the pilot and new participants did not differ significantly.

Prior to working with the programme, only $18 \%$ of all participants (pilot and new) fertilized their pastures, and even fewer used live fences or fodder banks. Although most (73\%) used electric wire to guide grazing, very few rotated their cattle through small parcels on a weekly or bi-weekly basis.

In interviews, when asked what they perceived to be their most important household needs (list two), the participants' top three responses were improved pasturelands (70\%), water $(45 \%)$ and food (32\%). Correspondingly, when asked about the silvopastoral programme benefits, participants consistently cited the fertilization of pasturelands as a principal benefit. This was followed by the provision of live fences, which, according to respondents, would relieve them from having to spend money (and trees) to replace the fence posts every couple of years and, in the future, would provide fuel wood and building materials. 
Table 1 Characteristics of participants in the Oak Corridor PES programme. $\mathrm{SD}=$ standard deviation.

\begin{tabular}{lrrrrrr}
\hline \hline Characteristic & Mean & Median & \multicolumn{1}{c}{ SD } & Minimum & Maximum & $n$ \\
\hline Age (years) & 43.92 & 42.50 & 12.88 & 20 & 76 & 76 \\
Education (years) & 4.50 & 4.00 & 2.89 & 0 & 14 & 76 \\
Household size (n) & 4.54 & 4.00 & 1.88 & 1 & 9 & 76 \\
Forest (ha) & 17.61 & 1.50 & 47.63 & 0.20 & 250.00 & 64 \\
Pasture (ha) & 10.06 & 5.00 & 15.33 & 0.60 & 90.00 & 73 \\
Cows (n) & 9.13 & 6.00 & 9.68 & 0 & 50 & 76 \\
\hline \hline
\end{tabular}

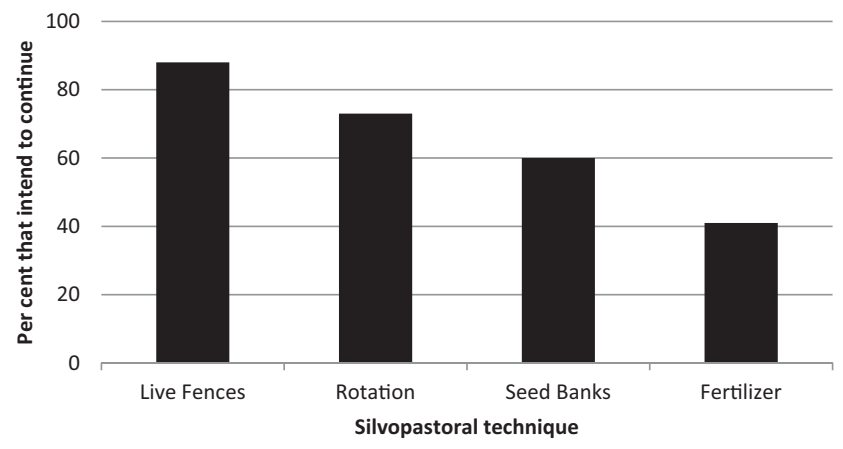

Figure 2 Stated intent to use silvopastoral techniques in future $(n=21)$.

\section{Stated likelihood to sustain the silvopastoral practices}

The results show that, despite farmers' explicit appreciation for the silvopastoral techniques, after completing the programme, few pilot participants stated that they would continue to use each new silvopastoral technique in the next year (Fig. 2). The most promising change in land-use behaviour appears to be the use of live fences. Less than half of the participants $(41 \%)$ stated that they were likely to continue to fertilize their fields, despite improvements in the production of their pastures.

\section{Perceived behavioural control}

The majority of farmers felt dependent on outside help to sustain the system as $60 \%$ of the farmers interviewed (pilot and new participants) stated that they could not make such farm-level changes without external help to provide materials and technical advice. Pilot participants were significantly more positive about their abilities to sustain the silvopastoral improvements than new participants were that they could begin without external assistance (Fig. 3; Pearson $\chi^{2}=$ $10.71, p=0.005)$. However, even after receiving the initial assistance package, many farmers did not perceive sufficient behavioural control in the form of resources, knowledge and motivation to continue with the project. Less than half of the pilot participants $(48 \%)$ were confident that they would be able to sustain the changes without additional external help. Common complaints were that they did not have the economic resources to maintain the silvopastoral system, particularly the fertilizers, and that they needed the extension agents to continue to provide them with information and the motivation to continue.

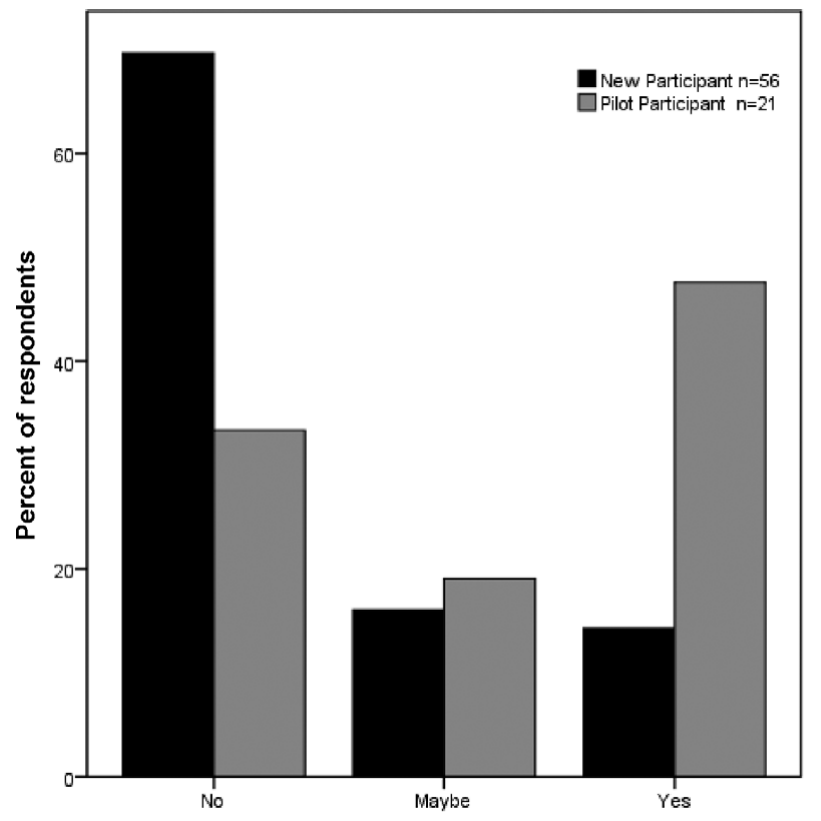

Implement silvopastoral technique without external assistance

Figure 3 Ability to implement and sustain silvopastoral system without external assistance.

\section{Perceived economic viability of silvopastoral practices}

Results from the Oak Corridor cast doubt on whether the linear economic decision-making model of the PES system accurately captures farmers' decision-making processes. In the Oak Corridor, programme specialists estimated that under the silvopastoral practices, and normal market conditions, milk production increased by $2-4$ bottles per cow per day, providing the average farmer with an additional 2580 5160 pesos $\mathrm{d}^{-1}$ or $c$. US\$ 43-86 $\mathrm{mo}^{-1}$ (CIPAV, personal communication July 2008). In order to sustain the system, at least part of this additional income must be invested in the farm in the form of fertilizers. However, when new participants were asked how they might spend an additional 100000 pesos (US\$ $55 \mathrm{mo}^{-1}$ ) earned from increased milk production, $48 \%$ responded that they would spend the additional income on food. This was followed by general household needs, buying additional cows and education. Only one participant specifically mentioned that he would spend the additional money to fertilize his pasturelands.

Interview results indicate that, in addition to more pressing household spending needs, the reluctance to spend any 
additional money on fertilizers may be due to the inability to identify the direct benefits from such investment in the pasturelands. Prior to starting the programme, $89 \%$ of the new participants stated that they thought that the programme would improve their farms greatly. After completing the programme, only $47 \%$ of the pilot farmers thought that the programme had greatly improved their farm. While many noted that their pastures improved $(62.5 \%)$, especially after the fertilization treatments, fewer (28\%) were able to link these changes to increases in milk production. Although the programme encouraged farmers to keep track of their milk production, extension agents reported that few did so, thereby making the gains in milk production difficult to perceive. Given alternative spending priorities, a feeling of dependency on outside support and, unclear production benefits, many farmers felt unwilling or unable to continue with the new silvopastoral practices.

\section{Perception of contracts and commitment to practices}

In interviews with the new participants, $80 \%$ supported the contract and stated that they believed that the NGOs have a legitimate right to create agreements restricting individuals' land uses. However, in describing the specifics of the contract, participants seemed unsure of their conservation measure commitments. When asked about the commitment of the NGOs, all stated that the NGOs would provide the materials and technical assistance. In return, $70 \%$ of the participants responded that their principal commitment was to provide the labour; $59 \%$ stated a commitment to protect the newlyplanted trees; but only $13 \%$ stated that they were required to conserve forests on their lands. While programme extension agents did threaten to expel farmers for non-compliance, the lack of understanding of the contract commitments and weak monitoring and enforcement mechanisms in the region produced minimal confidence that the contracts in themselves were serving to secure forest conservation.

\section{Adaptive capacity: self-determination, innovation and social learning}

With respect to self-determination over the programme practices, interview results showed that just $10 \%$ of the pilot participants considered the farmer the principal decisionmaker in the silvopastoral practices. Fifty per cent of the pilot participants responded that they considered the majority of the farm-level programme decisions to have been made jointly, and $40 \%$ considered programme extension agents to have been the principal decision-maker.

Furthermore, of the 21 pilot participants interviewed, only two participants stated that they had made any changes or innovations to better adapt the system to their own farm. Pilot participants were quick to respond that no, they had not modified the silvopastoral techniques in any way and, using similar language as that used to describe the contracts, they said that they continued to 'care for' the materials given to them.

The study did show evidence of informal social learning, as $58 \%$ of the new participants stated that seeing the pilot participants' experiences with the programme was a principal influence in opting to join the programme. In addition, pilot programme farmers were significantly more likely to have tried to teach their neighbour a farming technique than were new programme participants $(n=77$, continuity correction value $=10.828, p=0.001)$.

\section{DISCUSSION}

Findings from the Oak Corridor silvopastoral programme suggest that policymakers and practitioners need to reexamine the principal tenants of the PES system when applied to promote silvopastoral practices in poor rural peasant communities. First, the findings suggest that the PES decision-making model may not necessarily coincide with peasant farmers' decision-making processes. Although the programme has succeeded in convincing the majority of community members to participate in the silvopastoral programme, thereby planting hundreds of metres of live fences and designating thousands of hectares of forest for conservation (Oak Corridor programme specialist, personal communication 2009), after receiving financial and technical support to cover the initial start-up costs, less than half of the participants stated that they could continue to sustain the pasture management techniques without external assistance.

The disjuncture between the programme model and the farmers' land-use decisions can be explained in part by the farmers' perceptions of the initial start-up payments and their subsequent spending priorities for any additional household income. The results show that for the farmer, the initial startup investments were often perceived as short-term donations. When asked why they wanted to participate in the programme, many farmers responded 'por qué no?' (why not?) with approximately half citing programme materials, specifically the fertilizers and live fences, as the greatest programme benefit. Furthermore, very few farmers perceived a connection between increased milk profits and their responsibility to maintain the silvopastoral practices; only one farmer stated that he would use the additional profits from milk production to reinvest in his pasturelands. The majority stated that they were likely to spend any additional earnings on more pressing spending priorities such as food, household improvements and education.

Thus, for many farmers, the decision to participate in the silvopastoral programme was influenced by perceived immediate gains, not the illusive long-term benefits of the new management system. Although the programme plans to encourage farmers to consider the long-term benefits of the silvopastoral system by supporting more stringent record keeping of milk production and organizing a dairy cooperative that would further increase profits by reducing reliance on intermediaries and decrease transportation costs, 
this remains a long and complicated process with relatively distant economic benefits.

Second, the findings suggest that written contractual commitments that stipulate very specific land-use practices may not be appropriate for rural populations or dynamic landuse systems. In the Oak Corridor, one of the principal reasons for investing in the farmer's pasturelands is to ensure that the remaining forests are conserved. Although participants generally approved of the contract and felt that it gave the programme greater legitimacy, only $13 \%$ of the participants understood that in signing the contract they had committed to conserving their forests. Furthermore, many specifically stated that their responsibility was to 'care for' the materials given to them by the programme. This illustrates not only a vague understanding of their contractual commitments, but also a failure to establish ownership over the silvopastoral practices.

Thirdly, policymakers and practitioners must critically examine how the PES programme's use of externally mandated direct incentives and contingent contracts affects farmers' abilities to innovate, learn and adaptively manage their farms. Results from the Oak Corridor indicate that the use of contractual arrangements created a management model where farmers were rarely consulted about the landuse decisions, leaving them passive programme participants on their own farms, rather than collaborative partners (Biggs 1989). In interviews, very few participants considered themselves the principal decision maker in the implementation of the silvopastoral techniques. Furthermore, only one person had tried to adapt the techniques to fit his farm conditions. This is surprising, given that in informal conversations, a number of participants criticized the suitability of the original tree species used for the live fences and noted that the fodder banks often failed because the soil or altitude conditions on their farms were not suited to the fodder crops. PES proponents contend that direct payments based on contingent contracts offer a policy alternative that may be more effective and efficient at obtaining conservation goals than traditional command and control policies or elusive integrated conservation and development programmes (ICDPs) (Ferraro \& Kiss 2002; Wunder 2006). The results from this study suggest that PES programmes may still suffer from the ills of previous conservation and development programmes that prioritized outside expertise over local knowledge and assumed that economic incentives were sufficient to change land-use behaviours. Rather than dismissing past programmes, the PES approach could benefit from examining lessons from previous experiences in conservation and agricultural development, specifically in looking for ways to avert its top-down tendencies and engage with local resource users in the design and application of the programmes. Research on agricultural adoption and innovation finds that formal agricultural models and outside techniques can serve as a starting point for agricultural development, but that successful farm-level adoption demands farmer experimentation to modify and adapt land-use practices
(Johnson et al. 2003; Sumberg et al. 2003; Robbins \& Williams 2005; Shiferaw et al. 2009; Spielman et al. 2008). There are a number of ways in which the PES programme might move towards a more collaborative model of land-management that promotes farmer self-efficacy, innovation and adaptation. For example, increased farmer participation in writing the contracts and in selecting the land-use practices are means to incorporate local resource users' knowledge into PES policy design and ensure that local resource users understand their contractual commitments.

Agroecological approaches have a history of supporting farmer self-efficacy and decision-making autonomy by incorporating local knowledge and resources into land management practices (Bunch 1982; Altieri 2000; HoltGimenez 2006). In particular, the use of green manures, or leguminous plants, has been shown to enhance soil fertility while relying on locally produced resources (Nair 1985; Tilman 1998; Altieri 1999). While not a panacea for sustainable land management, such practices do reduce the need for external hand-outs and may correspond more accurately to farmers land-use strategies and provide production benefits without drawing on farmers' limited monetary funds.

Finally, participatory extension methods, such as farmerto-farmer training, farmer field schools, and local agricultural research committees that encourage experimentation and exchange of information between farmers and extension agents (see Chambers et al. 1989; Ashby \& Sperling 1995; Braun 2000; Godtland et al. 2004; Holt-Gimenez 2006), are ways to support farmer-driven adaptive management.

\section{CONCLUSIONS}

The Oak Corridor silvopastoral programme charts relatively new territory in forest governance by experimenting with, and adapting, PES schemes to fit the conservation and livelihood priorities in the region. PES proponents estimate that by 2030 , an array of PES arrangements could benefit up to 78 million low-income households in developing countries (Milder et al. 2010). However, these benefits will only be sustained if the programme is able to move away from policies that implement standardized programmes irrespective of the local conditions. If PES is to supersede previous ills in conservation and development, and the current critiques of neoliberal models, PES arrangements must incorporate farmers' perspectives of the problem and plausible solutions into the management plans. By integrating the farmer into the decision-making processes, PES can support a collaborative partnership that produces not only efficient conservation measures, but also provides farmers with the tools needed for sustained livelihood development and adaptive management.

\section{ACKNOWLEDGEMENTS}

I wish to acknowledge the funding support provided by Seattle University and logistical support provided by Fundación Natura, Colombia and CIPAV. Special thanks to Luis Mario 
Cárdenas and Fernando Diaz for their help in developing this analysis. And, many thanks to the participants at the IASC North American conference in Tempe Arizona, Felipe Murtinho and two anonymous reviewers for comments on earlier drafts of this paper. Any errors or omissions are my own.

\section{References}

Agrawal, A. \& Chhatre, A. (2007) State involvement and forest co-governance: evidence from the Indian Himalayas. Studies in Comparative International Development 42: 67-86.

Ajzen, I. (1991) The theory of planned behavior. Organizational Behavior and Human Decision Processes 50(2): 179-211.

Ajzen, I. (2006) Constructing a TpB questionnaire: conceptual and methodological considerations [www document]. URL http://www.uni-bielefeld.de/ikg/zick/ajzen\%20construction\% $20 \mathrm{a} \% 20 \mathrm{tpb} \% 20$ questionnaire.pdf

Altieri, M.A. (1999) Applying agroecology to enhance the productivity of peasant farming systems in Latin America. Environment, Development and Sustainability 1(3): 197-217.

Altieri, M.A. (2000) Developing sustainable agricultural systems for small farmers in Latin America. Natural Resources Forum 24(2): 97-105.

Angelsen, A. \& Kaimowitz, D. (1999) Rethinking the causes of deforestation: lessons from economic models. The World Bank Research Observer 14(1): 73-98.

Armenteras, D., Gast, F. \& Villareal, H. (2003) Andean forest fragmentation and the representativeness of protected natural areas in the Eastern Andes, Colombia. Biological Conservation 113(2): 245-256.

Armitage, D. (2005) Adaptive capacity and community-based natural resource management. Environmental Management 35(6): 703-715.

Ashby, J. (1985) The social ecology of soil erosion in a Colombian farming system. Rural Sociology 50(3): 377-396.

Ashby, J.A. \& Sperling, L. (1995) Institutionalizing participatory, client driven research and technology development in agriculture. Development and Change 26(4): 753-770.

Avella, A. \& Cárdenas, L.M. (2010) Conservación y uso sostenible de los bosques de roble en el corredor de conservación Guantiva-La Rusia-Iguaque, departamentos de Santander y Boyacá, Colombia. Colombia Forestal 13(1): 5-26.

Bandura, A. (1977) Self-efficacy: toward a unifying theory of behavioral change. Psychological Reviem 84(2): 191-215.

Biggs, S.D. (1989) Resource-poor farmer participation in research: a synthesis of experiences from nine national agricultural research systems. OFCOR Comparative Study Paper No. 3. The Hague, the Netherlands: ISNAR

Birner, R., Davis, K., Pender, J., Nkonya, E., Anandajayasekeram, P., Ekboir, J., Mbabu, A., Spielman, D. J., Horna, D. \& Benin, S. (2006) From' Best Practice' to' Best Fit': a Framemork for Analyzing Pluralistic Agricultural Advisory Services Worldwide. Washington, DC. USA: International Food Policy Research Institute.

Braun, A. R. (2000) Farmer Field Schools and Local Agricultural Research Committees: Complementary Platforms for Integrated Decision-Making in Sustainable Agriculture. London, UK: ODI

Bunch, R. (1982) Two Ears of Corn: a Guide to People Centered Agricultural Improvement. Oklahoma City, OK, USA: World Neighbors.
Bunch, R. (1999) Reasons for non-adoption of soil conservation technologies and how to overcome them. Mountain Research and Development 19(3): 213-220.

Cárdenas, J. C., Stranlund, J. \& Willis, C. (2000) Local environmental control and institutional crowding out. World Development 28(10): 1719-1733.

Chambers, R., Pacey, A. \& Thrupp, L.A., eds (1989) Farmer First: Farmer innovation and Agricultural Research. London, UK: Intermediate Technology Publications Ltd.

Clements, T., John, A., Nielsen, K., An, D., Tan, S. \& MilnerGulland, E. J. (2010) Payments for biodiversity conservation in the context of weak institutions: comparison of three programs from Cambodia. Ecological Economics 69: 1283-1291.

Dagang, A.B.K. \& Nair, P.K.R. (2003) Silvopastoral research and adoption in Central America: recent findings and recommendations for future directions. Agroforestry Systems 59: 149-155.

Dorward, A., Kydd, J., Morrison, J. \& Urey, I. (2004) A policy agenda for pro-poor agricultural growth. World Development 32(1): 73-89.

Engel, S., Pagiola, S. \& Wunder, S. (2008) Designing payments for environmental services in theory and practice: an overview of the issues. Ecological Economics 65: 663-674.

Escobar, A. (1998) Whose knowledge, whose nature? Biodiversity, conservation, and the political ecology of social movements. Journal of Political Ecology 5(1): 53-82.

Ferraro, P.J. (2008) Asymmetric information and contract design for payments for environmental services. Ecological Economics 65(4): 810-821.

Ferraro, P. \& Kiss, A. (2002) Ecology: direct payments to conserve biodiversity. Science 298(5599): 1718.

Folke, C., Hahn, T., Olsson, P. \& Norberg, J. (2005) Adaptive governance of social-ecological systems. Annual Reviem of Environment and Resources 30: 441-473.

Frey, B. \& Jegen, R. (2001) Motivation crowding theory. Fournal of Economic Surveys 15(5): 589-611.

Geist, H. \& Lambin, E. (2001) What drives tropical deforestation? a meta-analysis of approximate and underlying causes of deforestation based on subnational case study evidence. Report. LUCC Report Series, LUCC International Project Office, Louvain-la-Neuve, Belgium.

German, L., Mowo, J. \& Kingamkono, M. (2006) A methodology for tracking the 'fate' of technological interventions in agriculture. Agriculture and Human Values 23: 353-369.

Gneezy, U. \& Rustichini, A. (2000) Pay enough or don't pay at all. Quarterly Fournal of Economics 115(3): 791-810.

Godtland, E.M., Sadoulet, E., Janvry, A., Murgai, R. \& Ortiz, O. (2004) The impact of farmer field schools on knowledge and productivity: a study of potato farmers in the Peruvian Andes. Economic Development and Cultural Change 53(1): 63-92.

Grothmann, T. \& Patt, A. (2005) Adaptive capacity and human cognition: the process of individual adaptation to climate change. Global Environmental Change-Human and Policy Dimensions 15(3): 199-213.

Gsottbauer, E. \& van den Bergh, J. (2011) Environmental policy theory given bounded rationality and other-regarding preferences. Environmental and Resource Economics 49(2): 263-304.

Hagmann, J. \& Chuma, E. (2002) Enhancing the adaptive capacity of the resource users in natural resource management. Agricultural Systems 73(1): 23-39.

Hellin, J. \& Haigh, M. (2002) Better land husbandry in Honduras: towards the new paradigm in conserving soil, water and productivity. Land Degradation and Development 13(3): 233-250. 
Hellin, J. \& Schrader, K. (2003) The case against direct incentives and the search for alternative approaches to better land management in Central America. Agriculture, Ecosystems and Environment 99(1-3): 61-81.

Holden, S.T., Shiferaw, B. \& Wik, M. (1998) Poverty, market imperfections and time preferences: of relevance for environmental policy? Environment and Development Economics 3(1): 105-130.

Holt-Gimenez, E. (2006) Campesino A Campesino: Voices from Latin America's Farmer to Farmer Movement for Sustainable Agriculture. Oakland, CA, USA: Food First.

Igoe, J. \& Brockington, D. (2007) Neoliberal conservation: a brief introduction. Conservation and Society 5(4): 432.

Johnson, N.L., Lilja, N. \& Ashby, J.A. (2003) Measuring the impact of user participation in agricultural and natural resource management research. Agricultural Systems 78(2): 287-306.

Kiptot, E., Hebinck, P., Franzel, S. \& Richards, P. (2007) Adopters, testers or pseudo-adopters? Dynamics of the use of improved tree fallows by farmers in western Kenya. Agricultural Systems 94(2): 509-519.

León, M. \& Harvey, C. (2006) Live fences and landscape connectivity in a neotropical agricultural landscape. Agroforestry Systems 68(1): $15-26$.

Liverman, D. (2004) Who governs, at what scale and at what price? Geography, environmental governance, and the commodification of nature. Annals of the Association of American Geographers 94(4): 734-738.

Maddux, J.E. \& DuCharme, K.A. (1997) Behavioral intentions in theories of health behavior. In: Handbook of Health Behavior Research I, ed. D. S. Gochman, pp. 133-149. New York, NY, USA: Plenum Press.

McGinty, M.M., Swisher, M.E. \& Alavalapati, J. (2008) Agroforestry adoption and maintenance: self-efficacy, attitudes and socio-economic factors. Agroforestry Systems 73: 99-108.

Mercer, D.E. (2004) Adoption of agroforestry innovations in the tropics: a review. Agroforestry Systems 204411: 311-328.

Milder, J.C., Scherr, S.J. \& Bracer, C. (2010) Trends and future potential of payment for ecosystem services to alleviate rural poverty in developing countries. Ecology and Society 15(2): 4.

Muradian, R., Corbera, E., Pascual, U., Kosoy, N. \& May, P. (2010) Reconciling theory and practice: an alternative conceptual framework for understanding payments for environmental services. Ecological Economics 69: 1202-1208.

Murgueitio, E. (2009) Incentivos para los sistemas silvopastoriles en América Latina. Avances en Investigación Agropecuaria AIA 13(1): 3-19.

Murtinho, F., Eakin, H. \& Lopez-Carr, D. (2010) External Assistance Needed for Adaptation? An Assessment of Government Intervention in Local Water Management in the Colombian Andes. In: North American Regional Meeting of the International Association for the Study of the Commons, Tempe, Arizona: IASC. URL http://dlc.dlib.indiana.edu/dlc/handle/10535/6558

Nair, P.K.R. (1985) Classification of agroforestry systems. Agroforestry Systems 3(2): 97-128.

Ostrom, E. (1990) Governing the Commons: The Evolution of Institutions for Collective Action. New York, NY, USA: Cambridge University Press.

Pagiola, S., Arcenas, A. \& Platais, G. (2005) Can payments for environmental services help reduce poverty? An exploration of the issues and the evidence to date from Latin America. World Development 33(2): 237-253.
Pagiola, S., Ramírez, E., Gobbi, J., de Haan, C., Ibrahim, M., Murgueitio, E. \& Ruíz, J.P. (2007) Paying for the environmental services of silvopastoral practices in Nicaragua. Ecological Economics 64(2): 374-385.

Pagiola, S., Rios, A.R. \& Arcenas, A. (2008) Can the poor participate in payments for environmental services? lessons from the silvopastoral project in Nicaragua. Environment and Development Economics 13(3): 299-325.

Petheram, L. \& Campbell, B.M. (2010) Listening to locals on payments for environmental services. Fournal of Environmental Management 91(5): 1139-1149.

Pretty, J. \& Shah, P. (1997) Making soil and water conservation sustainable: from coercion and control to partnerships and participation. Land Degradation and Development 8(1): 3958.

Robbins, M. \& Williams, T. (2005) Scientific and Technical Advisory Panel to the Global Environmental Facility: land management and its benefits. The challenge, and the rationale for sustainable management of drylands. Washington, DC, USA: Global Environmental Facility Council [www document]. URL http://www.thegef.org/gef/sScieites/thegef.org/files/ documents/C.27.Inf_.11.Rev_.1\%20STAP.pdf

Shiferaw, B. A., Okello, J. \& Reddy, R. V. (2009) Adoption and adaptation of natural resource management innovations in smallholder agriculture: reflections on key lessons and best practices. Environment Development and Sustainability 11(3): 601619.

Solano, C. (2007) Corredor de Robles, una estrategia integrada de manejo y conservación de la biodiversidad en el marco del enfoque ecosistémico. In: Aplicación del Enfoque Ecosistémico en Latinoamérica. ed. Á. Andrade, pp. 32-36. Bogota, Colombia: IUCN.

Solano, C., Roa, C. \& Calle, Z. (2005) Estrategia de Desarrollo Sostenible en Corredor de Conservación. Bogota, Colombia: Fundacion Natura.

Spielman, D.J., Ekboir, J., Davis, K. \& Ochieng, C.M.O. (2008) An innovation systems perspective on strengthening agricultural education and training in sub-Saharan Africa. Agricultural Systems 98(1): 1-9.

Sullivan, S. (2009) Green capitalism, and the cultural poverty of constructing nature as service provider. Radical Anthropology 3: $18-27$.

Sumberg, J., Okali, C. \& Reece, D. (2003) Agricultural research in the face of diversity, local knowledge and the participation imperative: theoretical considerations. Agricultural Systems 76(2): 739-753.

Tilman, D. (1998) The greening of the green revolution. Nature 396(6708): 211-212.

van Dam, C. (2011) Indigenous territories and REDD in Latin America: opportunity or threat? Forests 2(1): 394-414.

van den Bergh, J.C.J.M., Ferrer-i-Carbonell, A. \& Munda, G. (2000) Alternative models of individual behaviour and implications for environmental policy. Ecological Economics 32(1): 4361.

Vatn, A. (2010) An institutional analysis of payments for environmental services. Ecological Economics 69: 1245-1252.

Vignola, R., Koellner, T., Scholz, R.W. \& McDaniels, T.L. (2010) Decision-making by farmers regarding ecosystem services: factors affecting soil conservation efforts in Costa Rica. Land Use Policy 27(4): 1132-1142.

Wilshusen, P., Brechin, S., Fortwangler, C. \& West, P. (2002) Reinventing a square wheel: critique of a resurgent 'protection 
paradigm' in international biodiversity conservation. Society and Natural Resources 15(1): 17-40.

Wunder, S. (2005) Payments for environmental services: some nuts and bolts.CIFOR Occasional Paper No. 24, CIFOR, Jakarta, Indonesia.
Wunder, S. (2006) Are direct payments for environmental services spelling doom for sustainable forest management in the tropics? Ecology and Society 11(2): 23 [www document]. URL http://www.ecologyandsociety.org/voll1/iss2/ $\operatorname{art} 23 /$ 